\title{
Evaluating the English Proficiency of Faculty Members of a Higher Education Institution: Using Results to Develop Responsive Professional Development Program
}

\author{
Joel C. Meniado ${ }^{1}$ \\ ${ }^{1}$ The Royal Commission for Jubail and Yanbu, Yanbu, Saudi Arabia \\ Correspondence: Joel C. Meniado, English Language Institute, Yanbu Industrial College, Yanbu, Al Madinah, \\ 41912, Saudi Arabia. E-mail: meniadoj@rcyci.edu.sa
}

Received: November 14, 2018

doi:10.5539/ijel.v9n2p52
Accepted: December 19, 2018 Online Published: January 30, 2019

URL: https://doi.org/10.5539/ijel.v9n2p52

\begin{abstract}
Current literatures reveal that English proficiency of Filipino workforce has declined through the years. The untrained and non-proficient teachers are heavily blamed on this pressing concern. With the aim of addressing the leading cause of the problem, this study investigated the level of English proficiency of faculty members of a higher education institution in the Philippines and proposed a program that could reverse the alarming trend. Utilizing mixed methods research design with 41 full-time faculty members as samples, this study found that majority of the teachers are in B1 and B2 levels (Intermediate and Upper Intermediate). In terms of specific language skill, writing is the lowest with majority of the teachers placed in A1 and A2 levels (Basic Users). Results of the study suggest that faculty members need to undergo several language enhancement courses such as Effective Communication, Academic and Professional Communication, Academic Writing with Research, and Effective Business and Report Writing, while the higher education institution involved in this study needs to support teachers in their formal higher studies, participation in workshops and trainings, publishing in scholarly journals, and serving as speakers or presenters in various academic forums. Discussion points that arise include implications of the findings and required actions from stakeholders. The study concludes with its limitations and important recommendations.
\end{abstract}

Keywords: English proficiency, Philippine higher education, faculty development program, language training, continuing professional development

\section{Introduction}

English has become the global lingua franca in education, business, politics, science, and technology. It is widely used as the medium of communication in acquiring and sharing information, performing business transactions, forging and sustaining relationships, discovering new knowledge, and creating new innovations. In a global context, English is used for integration and mobilization, sustainable development, human empowerment, international security, and environmental protection. At a micro level, on the other hand, English is used to promote equity and accessibility to economic and social development (International Consultants for Education \& Fairs, 2014).

In the Philippines, English language plays a very important role in every facet of Filipino's life. With English being one of the country's official languages, it is imperative that every Filipino knows how to use the language. Moreover, with government agencies and corporate organizations putting emphasis on fluency and accuracy in English communication as essential criteria in hiring, promoting, and developing employees, there is a need for every citizen to proficiently master the language even more.

However, in a study conducted by HA Cervantes Knowledge Systems, Inc. (Philippine Star, 2002), it was found that Filipino college graduates only have English proficiency at the basic working proficiency level. This was confirmed by a similar study conducted by EF Education First (Business Mirror, 2016) revealing that the English proficiency of Filipino workforce has indeed declined, negatively affecting Filipinos' global employability and foreign investment opportunities. The two previous findings were corroborated in the recent report of Hopkins International Partners (Morallo, 2018) stating that the average proficiency level of a Philippine college graduate is Intermediate (CEFR B1), two notches lower than the ideal proficiency level (CEFR C2). The Ateneo Center 
for English Language Teaching (ACELT, 2013) also found the same and urged authorities to do necessary actions for Filipinos not to lose one of their most useful assets in contributing to national development.

The declining English proficiency of Filipinos can be attributed to several factors. According to Wilson (2009), the untrained and non-proficient teachers contributed heavily to the problem. In a survey conducted by the Department of Education in 2008, it was found that 80 per cent of secondary school teachers in the Philippines failed an English proficiency exam. This shows teachers' low proficiency in English, hence producing graduates with relatively the same proficiency level. Other factors such as the country's bilingual policy, the adverse effects of media and information technology, erroneous English textbooks, and dwindling number of English television channels are also thought to have contributed to the problem (Wilson, 2009).

With the aim of addressing the leading cause of the problem, this study investigated the level of English proficiency of faculty members of a higher education institution in the Philippines and proposed a program that could alleviate the alarming concern. Specifically, it tried to answer the following questions: 1) What is the level of English proficiency of the respondents by macro-linguistic skill and overall? and 2) What specific faculty development program (language training) is appropriate for faculty members based on the results of their English proficiency test?

As teachers play essential role in the language proficiency development and enhancement of Filipino students, they must be proficient enough to influence students by serving as effective models in various instructional functions (Richards, 2011). When teachers are proficient in English, it is possible that students become proficient, too, as suggested in Bandura's Social Learning Theory, Krashen's Comprehensive Input Hypothesis, and Schumann's Acculturation Model of Second Language Acquisition (Orillos, 1998). Proficient teachers serving as models of fluency and accuracy in English can address the English language deficiencies and difficulties of students. Therefore, if the Philippine government is serious in reversing the trend of deteriorating English proficiency of Filipino students, teachers' English proficiency must be developed at the required threshold. Their existing English proficiency level in all four (4) macro-linguistic skills must be analyzed and evaluated, so that appropriate faculty development program on English language can be offered for them. It is when their linguistic needs, strengths, and weaknesses are identified that a responsive faculty development program is put in place, hence, this study.

This study is important to school administrators as it gives them baseline data on policy making particularly in hiring/selecting qualified employees/faculty members, in ranking and promotion, as well as in designing trainings and faculty development programs. It is also useful to teachers as it provides them a model or framework in identifying their English proficiency level as well as some development opportunities that can help them become better academic professionals. Lastly, it is valuable to future researchers since findings of this scholarly inquiry can contribute to the growing body of literature in the fields of language assessment, curriculum design, and teacher development. While this study investigated the English proficiency of faculty members in tertiary level, it was delimited to collecting available data on the English proficiency test scores/levels of the respondents and analyzing and utilizing these data in developing appropriate and relevant faculty development programs responsive to the identified needs and weaknesses. The proposed continuing professional development program presented was based on the results of evaluation and was designed for teachers teaching in the context of this study.

\section{Related Literature}

\subsection{English Proficiency}

Language proficiency has been viewed and defined in different ways. Noam Chomsky viewed it in two separate aspects - competence (grammatical knowledge) and performance (ability to use the language in actual situation) (Llurda, 2000). Hymes (1974) expanded this view by forming the concept of communicative competence. According to Hymes (1974), language proficiency involves knowledge about the grammatical systems of a language and the ability to use that knowledge in actual communicative situations. Canale and Swain (1980) also viewed language proficiency as a combination of three elements: linguistic competence, sociocultural, and strategic competencies. Linguistic competence refers to the knowledge of lexicon and the rules of morphology, semantics, phonology, and syntax, while sociolinguistic competence is the ability to appropriately use the language in social interactions. Strategic competence, on the other hand, is the ability to make repairs, to compensate communication breakdowns due to limited knowledge of rules, and to maintain communication by performing verbal and non-verbal mechanisms such as repeating, paraphrasing, hesitating, avoiding, guessing, and shifting registers and styles (Savignon, 1983). In addition to the three elements, Canale also introduced the concept of discourse competence which refers to the "ability to connect sentences in stretches of discourse and to 
form a meaningful whole out of a series of utterances" (Orillos, 1998, p. 78).

Harley et al. (1990), viewing in a broader perspective of communicative language teaching, define language proficiency as the ability to use a language appropriately in various situations and to organize one's thoughts through the language. In addition to competencies in English grammar and lexis, it also involves sociolinguistic and discourse competencies. The Council of Europe (2001) supports this definition through its Common European Framework of Reference (CEFR) for languages. According to the CEFR, language proficiency involves knowledge, skills, and characteristics acquired or learned to communicate with others (Ekola, 2016). It is divided into two categories: general (knowledge, skills, and existential competence) and communicative competences (linguistic, sociolinguistic, and pragmatic competences) (Ibid). Based on the above-mentioned views and definitions, it is clear that English language proficiency does not only entail mastery of the English language system but also the ability to use the language asserting appropriate functions in a particular social context. Further, it also involves awareness of different norms of interaction in native English and other varieties of English (Canagarajah, 2006).

English proficiency is categorized and described in various levels. The Common European Framework of Reference for Language Learning, Teaching, and Assessment (CEFR) is a popular guideline used to describe proficiency of foreign language learners worldwide (Council of Europe, 2001). It was designed to provide a method of learning, teaching, and assessing foreign languages. In 2001, it was used to set up systems of validation of language ability at six levels. Today, the six (6) reference levels are becoming widely accepted as the European and world standard for grading an individual's language proficiency. The Common European Framework categorizes learners into three broad divisions that can be divided into six levels: A1-Beginner; A2-Elementary; B1-Intermediate; B2-Upper Intermediate; C1-Advanced; and C2-Proficient (Ibid).

Several academic and language testing institutions exist to measure and evaluate English proficiency of learners and workers worldwide. Benchmarked with the CEFR proficiency levels, English language tests are utilized to determine readiness of individuals in handling tasks using English language as the medium of communication. In addition, they are also used to identify language training needs of employees and to evaluate the effectiveness of a language training program offered to specific employees. The International English Language Testing System (IELTS) developed by British Council, IDP IELTS Australia, and University of Cambridge ESOL Examinations is one of the renowned English proficiency tests worldwide. Comprising two modules (Academic and General Training), the test is administered for academic, employment, professional affiliation, and certification purposes. A test designed to assess language ability, it categorizes test takers into nine (9) types of users of the English language which can be grouped according to CEFR levels: Band Scores 1.0-3.5=A1-A2; 4.0-5.0=B1; $5.5-$ $6.5=\mathrm{B} 2 ; 7.0-7.5=\mathrm{C} 1$; and 8.0-9.0 $=\mathrm{C} 2$ (Cambridge English Language Assessment, 2018).

The Test of English as a Foreign Language-Internet-Based Test (TOEFL iBT), another equally renowned international English language proficiency test developed and administered by Educational Testing Service (ETS) in USA, also has its own language proficiency-leveling scheme. Covering the four (4) macro-linguistic skills, it categorizes test takers' performance into three (3): Low, Intermediate, and High (Educational Testing Service, 2018). It is used by educational institutions in admitting international students and in certifying foreign professionals who are non-native English speakers. In addition, it is also used by government and corporate organizations in hiring new employees.

Another international English language proficiency test for people whose native language is not English is the TOEIC (Test of English for International Communication). It measures the everyday English skills of people working in an international environment. The scores indicate how well people can communicate in English with others in business, commerce, and industry. It is mainly used for verifying one's level of English proficiency, qualifying for a new position and/or promotion in a company, enhancing one's professional credentials, monitoring progress in English, setting learning goals, and involving one's employer in advancing his English ability (Educational Testing Service, 2008).

\subsection{English Proficiency in the Workplace}

English is the language of power and progress. It is used to expand territories and increase human value. It is also used to promote competitiveness in a workplace, hence the need for any employee to develop desired proficiency level of the language. In the study of Mirabela and Ariana (2013), the value of developing English proficiency was explored. Based on the results, it was found that English proficiency is useful for workers to carry out effective communication, improve thinking, understand the world, get a rewarding career, attract clients, establish connections, and achieve personal satisfaction (Ibid). In another study conducted by the Education First (2014), it was found that English proficiency is a valuable asset in taking advantage of business 
opportunities, promoting international collaboration, and fostering innovation. It was also found that it is a strategic way to gain foothold in foreign markets and expand business territory. In another survey conducted by an Economic Intelligence Unit, it was revealed that English proficiency can significantly increase company profit, revenue, and market share (Ibid).

As English these days has become the de-facto language in international affairs, government and corporate organizations consider it as the most indispensable language for worldwide communication. In a survey conducted by Cambridge English Language Assessment (2016), it was revealed that 95\% of 5,373 employers in 38 non-native English-speaking countries believe that English language skills are essential in the workplace. It was also revealed that $56 \%$ of job tasks in abovementioned countries require at least advanced level in English, hence the need to develop workers with high level of English proficiency (Ibid).

In Thailand, English proficiency plays an important role in professional advancement and business functions. Workers use English in performing the following tasks in business environment: communicating through email, reading/writing memos, making proposals, presenting facts/figures, making phone calls, making oral presentations, reading/writing letters, making appointments, writing reports, negotiating, summarizing, greeting, making invitations, making complaints, and placing orders (Hiranburana, 2014).

In Australia, English proficiency also plays a crucial role in employment. Proficient applicants have higher opportunities to get a job, to perform well in the workplace, and get promoted to senior positions (Arkoudis et al., 2009). In the study of Roshid (2013), he explored the relationship of English language proficiency and employment of Bangladeshi immigrants in Australia. He found that one's English proficiency influences prospects of secure and better employment. Specifically, he found that English proficiency is a human capital that it can be an advantage to get a job with higher salary and employment benefits.

In the Middle East and North Africa (MENA) region, there is a positive relationship between English and the workplace. English proficiency is perceived to be important in driving economic growth and international development particularly in the business sector (British Council, 2013). It is also assumed that English proficiency of workforce can help attract foreign direct investments that can improve economic conditions and increase employment rate and earning power (Erling, 2015).

In the Philippines, English is the primary medium of communication in business and education; hence mastering the language has become a pre-requisite to success in academic and business environment (Digap, 2016). It opens doors for many career opportunities and helps improve one's employability skills. Through the years, Filipinos' proficiency in English language has helped the country's economy by attracting foreign investors, tourists, and ESL students (Cabigon, 2018). To maintain the country's advantage in the English language, the government in partnership with other non-government agencies and business sectors is taking actions to ensure prospective employees have at least an upper-intermediate proficiency level (CEFR B2 Level) in order to cope with the requirements and challenges of any job where English is the language (Romero, 2018). In the education sector, initiatives are implemented to produce and develop more qualified, highly trained English and content area teachers (Cabigon, 2018). For example, language training programs have been offered by various foreign missions and entities to teachers in the basic education institutions. In addition, the Department of Education has also implemented English Proficiency Test (EPT) as entry requirement for teacher applicants to ensure that they have the necessary proficiency level needed in producing English proficient students (Department of Education, 2018).

In the Philippine higher education, all universities, colleges, and institutes are mandated to produce globally competitive professionals who fit into the demands of international economy (Quijano, 2012). Institutions of higher education are compelled to develop skilled workforce who are proficient in English which is currently the language for worldwide communication. They are also directed by law to use the English language as the primary medium of instruction in the educational system to ensure quality education and economic growth (Besa, 2013). Therefore, all teaching and non-teaching staff are encouraged to use English in the teaching learning process as well as in all academic-related activities. Institutional policies on the use of English in higher education institutions require academic and non-academic professionals to be proficient in the language in order to carry out their work effectively and develop a sense of professional legitimacy.

\subsection{Faculty Development Programs in Higher Education}

Teachers play important roles in developing future nation builders and leaders by providing quality training and education. As such, they must have the necessary qualifications and competencies in order to achieve education outcomes. In the Philippines, faculty members of higher education institutions must have at least masters' degree in the fields in which they teach (Commission on Higher Education, 2018). In addition, they should also have the 
required 21st century skills (i.e., communication skills particularly in English, problem solving skills, information and communication technology skills, etc.) to be able to effectively and efficiently perform their duties and responsibilities. Unfortunately, recent data from the Commission on Higher Education (2018) show more than half of the higher education institutions (HEIs) faculty members need qualification upgrading and upskilling to be able to provide quality teaching in various HEIs. This calls for responsive faculty development programs or continuing professional development mechanisms in order to make HEI faculty members competitive agents for national transformation and economic development.

Faculty development program (FDP) is a set of activities designed to improve instruction and performance of students and learning institutions (Amundsen et al., 2015). It is a long-term process where teachers are engaged in various continuous professional development activities for skills improvement (i.e., curriculum development, instructional strategies, etc.) leading to the fulfillment of students' educational needs and school's vision and mission (Fink, 2013). Framed in training, mentoring, peer-coaching, and self-directed models (Yurtsever, 2013), faculty development can be in forms of personal, instructional, organizational, and professional activities (Amundsen et al., 2015). To be effective, a faculty development program should be theoretically and empirically based, responsive, practical, innovative, sustainable, collaborative, and reflective (Hismanoglu, 2010). Common types of faculty development activities include formal study in the graduate school, seminar-workshops, conferences, in-service training, research, mentoring, peer coaching, team teaching, study groups, and developing teaching portfolio.

Several studies have proven the effectiveness of faculty development programs in enhancing teachers' knowledge and skills leading to better quality of teaching and learning. In the study of Kamel (2016), it was found that professional FDP improves teaching skills in higher education by producing promising outcomes in the learning and teaching practices. Also, Bilal, Guraya and Chen (2017), in their study investigating the impact and effectiveness of FDP on faculty members' knowledge and competencies, found that FDP creates a significant and positive impact in enhancing faculty's knowledge and professional competence. Lastly, in the study of Dee and Daly (2009), it was shown that FDPs produce positive impact on teaching and learning, most especially when they are grassroots initiatives led by the faculty, when they promote inclusivity in teaching and learning, when they foster curricular and pedagogical transformation and multidisciplinary representation, and when they build connections and collaborations between and among stakeholders of higher education institutions.

In the field of English language teaching, Giraldo (2014) examined the impact of FDP on the classroom performance of English faculty members in a higher education institution. He found that FDPs improved faculty members' classroom performance as their teaching became more communicative, systematic, responsive to students' needs, and principled. Based on his findings, he suggested that FDPs, to be effective, 'must be based on teachers' philosophies and needs and effectively articulate theory, practice, experience, and reflection' (Giraldo, 2014, p. 1).

Since this study's aim is to develop and propose a faculty development program that enhances English proficiency of faculty members of a higher education institution in order to make them capable of producing communicative and English proficient graduates ready to compete in the global labor market, it is important to diagnose their strengths and weaknesses in using the English language. It is vital to know their language enhancement needs reflective of their knowledge, philosophies or attitudes, experiences, and insights in using and teaching the language. Addressing these needs can help teachers grow and develop within the concepts of 'Teaching English in English' and 'English-for-Teaching' (Richards, 2017; Freeman et al., 2015).

\section{Methodology}

\subsection{Research Design}

This study used the mixed methods approach. To determine the existing English proficiency levels of the HEI faculty members, the descriptive method was utilized. This method was deemed appropriate since the main aim of the study was to describe the existing phenomenon with respect to variables or conditions at a specific time (Mitchel \& Jolly, 2013). To identify relevant training programs based on the language training needs of the faculty members, the documentary analysis method was used. Existing literatures, public or private documents were examined thematically to use as data and references in developing the proposed FDP.

\subsection{Sample}

The study involved forty-one (41) full-time faculty members from the different colleges/departments of a small multi-disciplinary higher education institution in the Philippines. No sampling was done to yield more comprehensive and reliable results of the study. 


\subsection{Instrument}

To answer the question What is the level of English proficiency of the respondents by macro-linguistic skill and overall, available data on English proficiency of the faculty members were collected from records on file and from the teachers themselves. During the conduct of this study, valid English proficiency test results were used and were converted to CEFR Level equivalents to facilitate more unified and relevant analysis. CEFR standards were used as benchmarks because they include descriptors that reflect academic settings. Below is the summarized table of comparison using data from IELTS Partners (2018) and Educational Testing Service (Papageorgiou et al., 2015).

Table 1. Comparison of CEFR Levels with IELTS and TOEFL iBT ${ }^{\circledR}$ Scores

\begin{tabular}{lll}
\hline Common European Framework (CEFR) & IELTS $(0-9.0)$ & TOEFL iBT $(0-120)$ \\
\hline C2 (Proficient) & $8.5-9.0$ & $\mathrm{n} / \mathrm{a}$ \\
C1 (Advanced) & $7.0-8.0$ & 95 \\
B2 (Upper Intermediate) & $5.5-6.5$ & 72 \\
B1 (Intermediate) & $4.0-5.0$ & 42 \\
A2 (Elementary) & $\mathrm{n} / \mathrm{a}$ & $\mathrm{n} / \mathrm{a}$ \\
A1 (Beginner) & $\mathrm{n} / \mathrm{a}$ & $\mathrm{n} / \mathrm{a}$ \\
\hline
\end{tabular}

Note. The comparison is made between the individual test and the CEFR and not between the two tests mentioned.

To answer the question What specific faculty development program (language training) is appropriate for faculty members based on the results of their English proficiency test?, existing relevant literatures were used as sources of required data. Data gathered were coded or classified according to types or themes.

\subsection{Data Collection}

Before gathering the required data, permission from the school management was sought. Upon approval, employment records and profile of teachers were examined, including those that indicate existing proficiency levels of teachers. Faculty members were individually approached to verify or collect further information about their existing English proficiency test results. After gathering the English proficiency profile of teachers, documentary analysis was conducted to identify which professional development practices can be adopted to address language training needs of teachers on a particular proficiency level. Documents from the Commission on Higher Education, different colleges and universities, and various training organizations were analyzed thematically.

\subsection{Data Analysis}

The data gathered were analyzed using descriptive statistics (i.e., frequency and percentage computation). In rendering meaning to the collected data on English proficiency of the faculty members, the following CEFR Global Descriptors were used: 
Table 2. CEFR global descriptors

\begin{tabular}{|c|c|c|}
\hline Level & Description & Level Descriptors \\
\hline $\mathrm{C} 2$ & $\begin{array}{l}\text { Proficient User- } \\
\text { Mastery or Proficient }\end{array}$ & $\begin{array}{l}\text { Can understand with ease virtually everything heard or read. Can summarize information from } \\
\text { different spoken and written sources, reconstructing arguments and accounts in a coherent } \\
\text { presentation. Can express him/herself spontaneously, very fluently and precisely, differentiating } \\
\text { finer shades of meaning even in more complex situations. }\end{array}$ \\
\hline $\mathrm{C} 1$ & $\begin{array}{l}\text { Proficient User- } \\
\text { Effective Operational } \\
\text { Proficiency or } \\
\text { Advanced }\end{array}$ & $\begin{array}{l}\text { Can understand a wide range of demanding, longer texts, and recognize implicit meaning. Can } \\
\text { express him/herself fluently and spontaneously without much obvious searching for expressions. } \\
\text { Can use language flexibly and effectively for social, academic and professional purposes. Can } \\
\text { produce clear, well-structured, detailed text on complex subjects, showing controlled use of } \\
\text { organizational patterns, connectors and cohesive devices. }\end{array}$ \\
\hline B2 & $\begin{array}{l}\text { Independent User- } \\
\text { Vantage or Upper } \\
\text { Intermediate }\end{array}$ & $\begin{array}{l}\text { Can understand the main ideas of complex text on both concrete and abstract topics, including } \\
\text { technical discussions in his/her field of specialization. Can interact with a degree of fluency and } \\
\text { spontaneity that makes regular interaction with native speakers quite possible without strain for } \\
\text { either party. Can produce clear, detailed text on a wide range of subjects and explain a viewpoint } \\
\text { on a topical issue giving the advantages and disadvantages of various options. }\end{array}$ \\
\hline B1 & $\begin{array}{l}\text { Independent User- } \\
\text { Threshold or } \\
\text { Intermediate }\end{array}$ & $\begin{array}{l}\text { Can understand the main points of clear standard input on familiar matters regularly encountered } \\
\text { in work, school, leisure, etc. Can deal with most situations likely to arise whilst travelling in an } \\
\text { area where the language is spoken. Can produce simple connected text on topics which are } \\
\text { familiar or of personal interest. Can describe experiences and events, dreams, hopes \& ambitions } \\
\text { and briefly give reasons and explanations for opinions and plans. }\end{array}$ \\
\hline A2 & $\begin{array}{l}\text { Basic User-Waystage } \\
\text { or Elementary }\end{array}$ & $\begin{array}{l}\text { Can understand sentences and frequently used expressions related to areas of most immediate } \\
\text { relevance (e.g., very basic personal and family information, shopping, local geography, } \\
\text { employment). Can communicate in simple and routine tasks requiring a simple and direct } \\
\text { exchange of information on familiar and routine matters. Can describe in simple terms aspects of } \\
\text { his/her background, immediate environment and matters in areas of immediate need. }\end{array}$ \\
\hline A1 & $\begin{array}{l}\text { Basic User- } \\
\text { Breakthrough or } \\
\text { Beginner }\end{array}$ & $\begin{array}{l}\text { Can understand and use familiar everyday expressions and very basic phrases aimed at the } \\
\text { satisfaction of needs of a concrete type. Can introduce him/herself and others and can ask and } \\
\text { answer questions about personal details such as where he/she lives, people he/she knows and } \\
\text { things he/she has. Can interact in a simple way provided the other person talks slowly and } \\
\text { clearly and is prepared to help. }\end{array}$ \\
\hline
\end{tabular}

Note. Council of Europe, 2001, p. 25.

\section{Results}

\subsection{English Proficiency Level of the Faculty Members}

Table 3. Level of English proficiency of the respondents according to CEFR

\begin{tabular}{lllllllllll}
\hline CEFR Level & Listening & \multicolumn{3}{l}{ Speaking } & \multicolumn{2}{l}{ Reading } & \multicolumn{2}{l}{ Writing } & \multicolumn{2}{l}{ Overall Proficiency } \\
\hline & $\mathrm{F}$ & $\%$ & $\mathrm{~F}$ & $\%$ & $\mathrm{~F}$ & $\%$ & $\mathrm{~F}$ & $\%$ & $\mathrm{~F}$ & $\%$ \\
$\mathrm{C} 2$ & 0 & 0.00 & 0 & 0.00 & 0 & 0.00 & 0 & 0.00 & 0 & 0.00 \\
$\mathrm{C} 1$ & 1 & 2.44 & 9 & 21.95 & 4 & 9.76 & 0 & 0.00 & 1 & 2.44 \\
$\mathrm{~B} 2$ & 18 & 43.90 & 12 & 29.27 & 22 & 53.66 & 6 & 14.63 & 15 & 36.58 \\
$\mathrm{~B} 1$ & 15 & 36.59 & 15 & 36.58 & 10 & 24.39 & 19 & 46.34 & 21 & 51.22 \\
A2 & 6 & 14.63 & 5 & 12.20 & 5 & 12.19 & 14 & 34.14 & 3 & 7.32 \\
A1 & 1 & 2.44 & 0 & 0.00 & 0 & 0.00 & 2 & 4.88 & 1 & 2.44 \\
Total & 41 & 100.00 & 41 & 100.00 & 41 & 100.00 & 41 & 100.00 & 41 & 100.00 \\
\hline
\end{tabular}

Table 3 shows the frequency and percentage distribution of the CEFR proficiency levels of the HEI faculty members according to macro-linguistic skills and overall proficiency. Generally, in terms of overall English proficiency performance, more than half of the subjects of this study have B1 (Independent User-Intermediate) proficiency level while more than one-third has B2 (Independent User-Upper Intermediate) proficiency level. Majority of the faculty members seem to be in the zones of independent users of the English language.

Closely examining the table further reveals that when proficiency levels are grouped according to macro-linguistic skills, over half of the subjects are placed in the B1 and B2 levels combined (Independent Users), followed by those at the A2 (Elementary) level with an average of almost 10 percent. In terms of specific language skill, writing seems to be the weakest of the faculty members with 33 or 80.48 percent placed in the A1 and A2 levels (Basic Users). This shows that 4 in 5 teachers may have difficulty in writing using the English 
language. Listening, Reading, and Speaking also seem to be areas of concern since majority of the subjects fall in B1 and B2 levels. Only an average of 3.5 percent of the respondents are in C1 level (Advanced User) while nobody $(0 \%)$ in $\mathrm{C} 2$, the ideal proficiency level for HEI faculty members.

\subsection{Appropriate Faculty Development Program Based on the Results of the English Language Proficiency Evaluation}

Table 4. Institutional faculty development programs for English language proficiency enhancement

\begin{tabular}{|c|c|}
\hline Program & Description \\
\hline Support for Graduate Studies & $\begin{array}{l}\text { This program aims to raise faculty members' qualifications, help them develop scholarly attitudes } \\
\text { and get exposed to higher and more complex academic discourses by supporting them to pursue } \\
\text { their higher studies through available institutional grants, scholarships or external funding. }\end{array}$ \\
\hline $\begin{array}{l}\text { Support for Advanced } \\
\text { Short-term English Courses }\end{array}$ & $\begin{array}{l}\text { This program aims to strengthen the faculty members' overall English proficiency particularly their } \\
\text { writing skill through intensive, customized language training courses such as Academic and } \\
\text { Professional Communication, Advanced Academic Writing, Effective Business and Report Writing, } \\
\text { Advanced Grammar and Vocabulary, and Powerful Presentation Skills. }\end{array}$ \\
\hline $\begin{array}{l}\text { Support for Local Trainings, } \\
\text { Seminars, and Workshops on } \\
\text { English Proficiency } \\
\text { Enhancement }\end{array}$ & $\begin{array}{l}\text { This program provides various language learning opportunities for faculty members in order to } \\
\text { develop broader perspectives on the applicability of the English language. This includes sending } \\
\text { them to learner-centered, culturally sensitive, efficient, and effective language trainings, seminars, } \\
\text { workshops, or conferences or supporting them to become members of learning groups and } \\
\text { professional organizations. }\end{array}$ \\
\hline $\begin{array}{l}\text { Incentives for Publication in } \\
\text { Research Journals }\end{array}$ & $\begin{array}{l}\text { With the aim of developing research-driven and innovative faculty members while enhancing their } \\
\text { written and critical thinking skills, this program monetarily compensates teachers who are able to } \\
\text { write and publish articles in local and international refereed journals. }\end{array}$ \\
\hline $\begin{array}{l}\text { Support for paper presentations } \\
\text { in conferences }\end{array}$ & $\begin{array}{l}\text { This program supports faculty members when they present papers or deliver keynote presentations } \\
\text { or as invited speakers in prestigious conferences, workshops, symposia, and similar fora. }\end{array}$ \\
\hline
\end{tabular}

Table 4 shows the general faculty development programs applicable to the subjects of this study. These include formal higher studies in the graduate school, participation in seminars, workshops, and conferences, conducting researches publishable in scholarly journals, and serving as speakers or presenters in conferences, seminars, workshops, and similar academic forums. These programs have direct and indirect impact on the enhancement of English proficiency of faculty members since these provide ample opportunities for them to use the English language. Specifically, these programs immerse and engage faculty members with plenty of writing activities, hence addressing their identified language training need.

Table 5. Proposed language courses to enhance faculty members' English proficiency

\begin{tabular}{|c|c|}
\hline Course & Description \\
\hline $\begin{array}{l}\text { Effective } \\
\text { Communication }\end{array}$ & $\begin{array}{l}\text { This is a 48-hour course designed to enhance faculty members' listening, speaking, reading, and writing } \\
\text { skills. It helps learners improve their ability to communicate effectively and gain confidence in } \\
\text { communicating with other people. It includes grammar brush-ups and vocabulary enrichment activities. It } \\
\text { also covers writing effective sentences, paragraphs, and compositions/essays. Lastly, it includes writing } \\
\text { business letters, emails, memos, reports, proposals, and effective presentation skills. }\end{array}$ \\
\hline $\begin{array}{l}\text { Academic and } \\
\text { Professional } \\
\text { Communication }\end{array}$ & $\begin{array}{l}\text { This } 48 \text {-hour course trains participants to: a) demonstrate desirable communicative competence in English; } \\
\text { b) draft, compose and present a researched report on an aspect of their major; c) conduct correspondences } \\
\text { relating to professional and/or academic issues; d) use appropriate vocabulary and expressions; and e) } \\
\text { appreciate the role of ethics in communication. }\end{array}$ \\
\hline $\begin{array}{l}\text { Academic Writing } \\
\text { (with Research) }\end{array}$ & $\begin{array}{l}\text { This course is designed to help learners improve their reading and writing skills in academic context, } \\
\text { enhance their understanding of the theory and conventions of academic writing and research, and produce } \\
\text { scholarly written outputs following the universally accepted systems and standards. }\end{array}$ \\
\hline $\begin{array}{l}\text { Effective Business } \\
\text { and Report Writing }\end{array}$ & $\begin{array}{l}\text { This } 48 \text {-hour course allows participants to develop awareness of the importance of effective } \\
\text { communication in academics and business, apply the principles and conventions of business and technical } \\
\text { report writing in professional contexts, and improve their general usage of English as well as the mechanics } \\
\text { of business writing in business communication situations. }\end{array}$ \\
\hline
\end{tabular}

Table 5 shows the language courses designed to help faculty members improve their English proficiency in general and writing skill in particular. These specialized in-house courses cover topics in technical, academic, and workplace settings. While they are designed to develop faculty members' writing skill in various contexts, 
they are also integrative of other language skills such listening, speaking, and reading. Conducted by batch/group throughout the school year, the courses can be delivered in different modes such as face-to-face, online, or blended, in partnership with renowned language training institutions or teacher training agencies in the country (i.e., British Council, Cambridge English, etc.)

\section{Discussion}

In the Philippine higher education institutions, English is the main medium of communication, instruction, and assessment. As such, faculty members are expected to have high proficiency in English to effectively and efficiently carryout their duties and responsibilities for the institution and for the students. However, results of this study indicate that none of the subjects (HEI faculty members) are Proficient Users of the English language. Majority is placed under B1 and B2 in terms of overall performance in the English proficiency tests. The results confirm previous research findings claiming that most Filipino college/university graduates and working professionals have English proficiency at B1 or Intermediate Level (HACKSI, 2002; Hopkins International Partners in Morallo, 2018). However, they seem to be the opposite of the findings of Education First (Business Mirror, 2016) in its worldwide study reporting that though there has been a slight decline in recent years Filipino learners and workers still have very high English proficiency. Variations in findings can be attributed to the different tools, time frame, and methodologies used in gathering data. HACKSI and Hopkins International Partners used TOEIC results. Education First, on the other hand, used its own EFSET test, while the current study utilized results from IELTS and TOEFL iBT tests, which are more academic in nature. Apparently, English proficiency results can change through time with the influence of some variables.

Based on the results of the study, the subjects (faculty members) are categorized as Independent Users of the English language. This means that they may encounter difficulties in performing linguistic tasks or functions that are required in their work involving 'understanding a wide range of demanding, longer texts, and recognizing implicit meaning, expressing themselves fluently and spontaneously without much obvious searching for expressions, using language flexibly and effectively for social, academic and professional purposes, and producing clear, well-structured, detailed text on complex subjects, showing controlled use of organizational patterns, connectors and cohesive devices' (Council of Europe, 2001, p. 25). Further, they may also struggle in 'understanding with ease virtually everything heard or read, summarizing information from different spoken and written sources, reconstructing arguments and accounts in a coherent presentation, and expressing themselves spontaneously, very fluently and precisely, differentiating finer shades of meaning even in more complex situations' (Council of Europe, 2001, p. 25).

In terms of writing, majority of the faculty members are at the level of A2 (Elementary) and B1 (Intermediate), relatively lower than the expected level for teachers working in the tertiary level. This implies that they can easily write simple notes and messages relevant to immediate needs or simple connected texts on familiar topics or personal interests. They can also write simple personal letters thanking someone or describing experiences or impressions. However, they may find difficulties in performing linguistic tasks relevant to their work such as writing informative, explanatory, or argumentative essays, reports, or letters highlighting personal significance of events and experiences. Moreover, they may also struggle expressing themselves in clear, well-structured, style-appropriate texts of complex subjects expressing opinions or perspectives at some length with salient issues highlighted. Lastly, they may also find it difficult to write clear, cohesive, and complex yet style-appropriate letters, reports, or articles (i.e., summaries and reviews of professional or literary works) which present logically structured arguments highlighting significant points (Council of Europe, 2001).

Given the possible difficulties, faculty members need development programs that can make them more proficient in English in general and better writers in particular. These could range from institutional policies down to departmental professional activities designed to enhance teachers' English proficiency. In this study, the proposed programs include institutional support for graduate studies, participation in workshops or conferences, faculty research and publication, and conference presentation, related to those types outlined by Hismanoglu (2010). These commonly used programs may not have direct immediate impact on teachers' English proficiency but their effects are long-term and sustainable. Their continuous involvement and engagement can eventually make them more proficient and confident in using the English language. This study also proposed specific language courses to directly address the weakest language skill of teachers which is writing. It is important that the courses are designed based on the identified needs of participants (Giraldo, 2014) with some considerations on practicality, innovativeness, and sustainability in order to achieve the desired results (Hismanoglu, 2010).

\section{Conclusion}

Findings of the study reveal that the overall English proficiency level of the faculty members is B1 (Independent 
User-Intermediate) and that writing is the weakest among the four (4) macro-linguistic skills. With majority of faculty members categorized as Independent Users (B1 and B2 Levels), results suggest that they may encounter some difficulties in performing complex and demanding linguistic tasks related to the nature of their work. Results further suggest that with teachers not meeting the required or desirable proficiency threshold, they may not be effective models of good English for tertiary level students, hence developing college graduates who are non-proficient. It is therefore imperative that these faculty members undergo long-term and short-term faculty development programs particularly language enhancement programs (i.e., Effective Communication, Academic and Professional Communication, Academic Writing with Research, and Effective Business and Report Writing) in order to improve their proficiency levels. This will allow them to become better teachers capable of producing English proficient and globally competitive graduates.

While this study found that the proficiency levels of the faculty members by macro-linguistic skills and overall are relatively lower than the required or desired English language proficiency threshold for the teaching profession, it does not necessarily mean that they cannot generally and operationally communicate in English as they carry out their duties and responsibilities in teaching. It simply implies that there seems much to be done if the higher education institution in the context of this study aims to be at par with its national and international counterparts in other parts of the globe. Looking back to the alarming English proficiency problem at a national scale, Philippine higher education institutions have to develop faculty members in all aspects of their work in order to become effective actors and players for national and international development.

Though this study yielded results that can confirm and supplement existing literatures on the current status of English proficiency of teachers in the Philippines, it acknowledges its limitations on generalizability and reliability considering its scope, design and methodology, and time frame. The study dealt only with proficiency data that were collected from existing documents on file. Analysis was also limited due to the unavailability of complete and more detailed equivalency of proficiency test scores with the CEFR. More intensive study along this line of inquiry using single or uniform source of proficiency data should be conducted to produce more accurate and reliable findings.

\section{References}

Amundsen, C. et al. (2005). The what and the why of faculty development in higher education: An in-depth review of literature. Retrieved from http://www.sfu.ca/rethinkingteaching/publications/CAmundsen.etal.pdf

Arkoudis, S. (2009). The impact of English language proficiency and workplace readiness on the employment outcomes of tertiary international students. Retrieved from https://trove.nla.gov.au/version/217788187
Ateneo Center for English Language
https://www.ateneo.edu/ls/acelt/about-acelt
Teaching.
(2013).
ACELT.
Retrieved from

Besa, L. M. (2014). Language use in the university: A clash of policies. Procedia - Social and Behavioral Sciences, 134, 92-100. https://doi.org/10.1016/j.sbspro.2014.04.226

Bilal, Guraya, S. Y., \& Chen, S. (2017, October 18). The impact and effectiveness of faculty development program in fostering the faculty's knowledge, skills, and professional competence: A systematic review and meta-analysis. Saudi Journal of Biological Sciences. https://doi.org/10.1016/j.sjbs.2017.10.024

British Council. (2013). The English Effect. Retrieved from https://www.britishcouncil.org/sites/default/files/english-effect-report-v2.pdf

Business Mirror. (2016, November 23). Our shrinking English proficient work force. Business Mirror. Retrieved from https://businessmirror.com.ph/our-shrinking-english-proficient-work-force/

Cabigon, M. (2018). State of English in the Philippines: Should we be concerned? Retrieved from https://www.britishcouncil.ph/teach/state-english-philippines-should-we-be-concerned-2

Cambridge English Language Assessment. (2016). English at work: Global analysis of language skills in the workplace. Cambridge: University of Cambridge Local Examination Syndicate.

Cambridge English Language Assessment. (2018). Comparing scores to IELTS: B2 first and C1 advanced. Cambridge: University of Cambridge Local Examination Syndicate.

Canagarajah, S. (2006). Changing communicative needs, revised assessment objectives: Testing English as an international language. Language Assessment Quarterly, 3(3), 229-242. https://doi.org/10.1207/s15434311laq0303_1 
Canale, M. (1983). From communicative competence to communicative language pedagogy. In J. C. Richards \& R. W. Schmidt (Eds.), Language and Communication (pp. 2-27). London: Longman.

Canale, M., \& Swain, M. (1980). Theoretical bases of communicative approaches to second language teaching and testing. Applied Linguistics, 1(1), 1-47. https://doi.org/10.1093/applin/I.1.1

Commission on Higher Education. (2018). Faculty Development Program. Retrieved from https://ched.gov.ph/faculty-development-program-facdev/

Council of Europe. (2001). Common European framework of reference for languages: Learning, teaching, assessment. Cambridge: Cambridge University Press.

Dee, J. R., \& Daly, C. J. (2009). Innovative models of organizing faculty development programs: Pedagogical reflexivity, student learning empathy, and faculty agency. Human Architecture: Journal of the Sociology of Self-Knowledge, 7(1), 1-22. Retrieved from https://scholarworks.umb.edu/humanarchitecture/vol7/iss1/2/

Department of Education. (2018). Administration of the teachers' English proficiency test and the process skills test in science and mathematics. Retrieved from http://www.deped.gov.ph/wp-content/uploads/2018/10/DM_s2018_145.pdf

Digap, A. L. (2016). Self-efficacy, English proficiency and effectiveness of teachers of English in the secondary schools. SMCC Higher Education Research Journal, 2(April), 72-88. https://doi.org/10.18868/sher2j.02.00416.07

Educational Testing Service. (2008). TOEIC Examinee Handbook: Listening \& Reading. New Jersey: Educational Testing Service

Educational Testing Service. (2018). Interpret TOEFL ${ }^{\circledR} \quad$ Scores. Retrieved from https://www.ets.org/toefl/institutions/scores/interpret/

EF Education First. (2014). EF EPI-c: EF English Proficiency Index for Companies. Luzern: EF Learning Labs. Retrieved from https://www.ef.com/_/ / media/centralefcom/epi/v4/downloads/epi-c/ef-epi-c-english-191114.pdf

EF Education First. (2016). EF EPI: Education First English Proficiency Index. Retrieved from https://www.ef.com/_/ /media/centralefcom/epi/downloads/full-reports/v6/ef-epi-2016-english.pdf

EF Education First. (2018). EF EPI: EF English Proficiency Index. Retrieved from https://www.ef.com/__ / media/centralefcom/epi/downloads/full-reports/v8/ef-epi-2018-english.pdf

Ekola, T. (2016). English language needs and language proficiency of academic professionals as a basis for developing language training: A case study of environmental researchers. Retrieved from https://jyx.jyu.fi/bitstream/handle/123456789/53038/1/URN\%3ANBN\%3Afi\%3Ajyu-201702141439.pdf

Erling, E. (2015). The relationship between English and employability in the Middle East and North Africa. Manchester: British Council.

Fink, L. D. (2013). The current status of faculty development internationally. International Journal for the Scholarship of Teaching and Learning, 7(2), 1-9. https://doi.org/10.20429/ijsotl.2013.070204

Freeman, D., et al. (2015). English for teaching: Rethinking teacher proficiency in the classroom. ELT Journal, 69(2), 129-139. https://doi.org/10.1093/elt/ccu074

Giraldo, F. (2014). The impact of a professional development program on English language teachers' classroom performance. Profile: Issues in Teachers' Professional Development, 16(1), 63. https://doi.org/10.15446/profile.v16n1.38150

Harley et al. (1990). The development of second language proficiency. Cambridge: Cambridge University Press. https://doi.org/10.1017/CBO9781139524568

Hiranburana, K. (2017). Use of English in the Thai workplace. Kasetsart Journal of Social Sciences, 38, 31-38. https://doi.org/10.1016/j.kjss.2015.10.002

Hismanoglu, M. (2010). Effective professional development strategies of English language teachers. Procedia Social and Behavioral Sciences, 2, 990-995. https://doi.org/10.1016/j.sbspro.2010.03.139

Hymes, D. (1974). Foundations on linguistics: An ethnographic approach. Philadelphia: University of Pennsylvania Press. 
IELTS Partners. (2018). Common European Framework: How should the CEFR be used by recognizing institutions wishing to set language ability requirements? Retrieved from https://www.ielts.org/ielts-for-organisations/common-european-framework

International Consultants for Education and Fairs. (2014, January 29). Global language survey links English proficiency to economic and social development. ICEF Monitor. Retrieved from http://monitor.icef.com/2014/01/global-language-survey-links-english-proficiency-to-economic-and-socialdevelopment/

Kamel, A. M. (2016). Role of faculty development programs in improving teaching and learning. Saudi Journal of Oral Sciences, 3(2), 61-68. https://doi.org/10.4103/1658-6816.188073

Llurda, E. (2000). On competence, proficiency, and communicative language ability. International Journal of Applied Linguistics, 10(1), 85-96. https://doi.org/10.1111/j.1473-4192.2000.tb00141.x

Mirabela, P. A., \& Ariana, A. M. (2013). Benefits of English language learning-language proficiency certificates: A prerequisite for the business graduate. Annals of Faculty of Economics (University of Oradea, Faculty of Economics), 1(2), 167-176. $\quad$ Retrieved from https://ideas.repec.org/a/ora/journl/v1y2013i2p167-176.html

Mitchel, M. L., \& Jolley, J. M. (2013). Research design explained. California: Cengage Learning.

Morallo, A. (2018, February 8). Filipino graduates' English skills lower than target cab drivers in Dubai, study says. Philippine Star. Retrieved from https://www.philstar.com/headlines/2018/02/08/1785840/filipino-graduates-english-skills-lower-target-cabdrivers-dubai-study-says

Orillos, L. Q. (1998). Language acquisition theories, principles, and research. Quezon City: UP Open University

Papageorgiou, S., et al. (2015). Research Memorandum ETS RM-15-06: The association between TOEFL iBT test scores and the Common European Framework of Reference (CEFR) levels. New Jersey: Educational Testing Service.

Philippine Star. (2002, April 10). Study shows Filipino college students not proficient in English. Philippine Star. Retrieved from https://www.philstar.com/business/2002/04/10/156748/study-shows-filipino-college-studes-not-proficient-e nglish

Quijano, C. (2012). Philippines: The role of language and education in globalization. Retrieved from https://files.eric.ed.gov/fulltext/ED567190.pdf

Richards, J. C. (2011). Competence and performance in language teaching. Cambridge: Cambridge University Press.

Richards, J. C. (2017). Teaching English through English: Proficiency, pedagogy and performance. RELC Journal, 48(1), 7-30. https://doi.org/10.1177/0033688217690059

Romero, P. (2018, February 22). Senate to probe declining English proficiency. Philippine Star. Retrieved from https://www.philstar.com/other-sections/education-and-home/2018/02/22/1790069/senate-probe-decliningenglish-proficiency

Roshid, M. M. (2013). English language proficiency and employment: A case study of Bangladeshi graduates in Australian employment market. Mevlana International Journal of Education, 3(1), 68-81. https://doi.org/10.13054/mije.13.06.3.1

Savignon, S. J. (1983). Communicative competence: Theory and classroom practice. Reading, MA: Addison-Wesley Publishing.

Wilson, K. (2009, November 10). Teachers blamed as English standards fall in the Philippines. The National. Retrieved from https://www.thenational.ae/world/asia/teachers-blamed-as-english-standards-fall-in-philippines-1.530443

Yurtsever, G. (2013). English language instructors' beliefs on professional development models and preferences to improve their teaching skills. Procedia - Social and Behavioral Sciences, 70, 666-674. https://doi.org/10.1016/j.sbspro.2013.01.107 


\section{Copyrights}

Copyright for this article is retained by the author, with first publication rights granted to the journal.

This is an open-access article distributed under the terms and conditions of the Creative Commons Attribution license (http://creativecommons.org/licenses/by/4.0/). 